\title{
Prevalence of Endo and Ecto Parasitic Infection of African Giant Rat (Cricetomys gambianus) in North Eastern Nigeria
}

\author{
Adamu Muhammad Abdullahi', Sadiq Gambo Mamman ${ }^{2}$ \\ ${ }^{1}$ Department of Health Information Management, College of Health Sciences and Technology Nguru, \\ Yobe State Nigeria \\ ${ }^{2}$ Department of Operation, Federal Road Safety Corps, Nigeria \\ Corresponding Author: Adamu Muhammad Abdullahi
}

\begin{abstract}
Rodents are one of the most important groups of mammalian animal with more than $42 \%$ of the known mammalian species, with 1700 species which belongs to three different families include Muridae, microtidaie and sigmodontidae. The aim of this study is to examine endo and ecto parasitic infection of African Giant rat (Cricetomys Gambianus). Intestinal parasite were detected and identified from the stool samples using formalin ethyl-acetate concentration technique. A total of 18 African giant rats were captured, all of the captured rats were found infected with at least one or more endoparasites $(100 \%)$. Whereas there's no any ectoparasites identified from the rat. $16(89 \%)$ of the rats captured were found positive for haemoparasite. Therefore, the results of this study have shown that the rats are infected with parasite species that may play an important role in transmission of certain zoonotic diseases to humans.
\end{abstract}

Keywords: African Giant rat, Cricetomys Gambianus, endo and ecto parasitic infection, Rodents, zoonotic disease

\section{INTRODUCTION}

Giant rat (Cricetomys Gambianus) is one of the wild rodents found inhabiting different habitats in Africa and other parts of the world (Ajayi 1975). C. Gambianus is a source of food to many people in Africa and it has been known to be a cheap source of protein for the common man (Ekeh et al.,
2009). C. Gambianus mainly lives in the savanna around the edges of forest and in the mountain up to $3,500 \mathrm{~m}$ above sea level. It can also be found in sub-Saharan Africa and North Eastern region of South African (Luniak, 2004). They are solitary animal, with nocturnal habits and prefer to live in burrows. It feeds on large varieties of plant and animal foods, such as tubers, grains and nuts. In its natural habit, it is a very prolific breeder. The duration of gestation is approximately one month; a female Gambian rat can reproduce six times in one year (Ekeh et al., 2009).

In spite of their economic importance, different rodent species harbor a variety of endoparasites and ectoparasites, thus posing threats to human public health (Smith 1955). Human mostly get infected with rodents associated parasites, when the parasitic eggs are passed out in rodent faeces on agricultural fields, stored grains and in a range of edible commodities in houses and accordingly responsible for spread of the disease. Their capacity to act as a vector is seriously improved due to their physiological similarities which they distribute with humans (World Health Organization 2018). Consequently, increased rodent population in a region could be directly related to increased zoonotic diseases in human population (Mustapha et al., 2019). 
In spite several of previous studies on parasites of rodents in Nigeria still there is a paucity of information regarding parasites of the wild rodents in the semi-arid region of Northeastern Nigeria. This study was therefore, designed to study the internal, external as well as the haemoparasitic infections of the African giant rat (Cricetomys Gambianus) in the semi-arid region of northeastern Nigeria, with a view of knowing its zoonotic implication and for enhancing its ex - situ conservation.

\section{MATERIAL AND METHODS Study area}

The survey was conducted in Maiduguri city and Yobe, located between latitude $115 \mathrm{~N}$ and longitude $135 \mathrm{E}$. It occupies an area of 50, 778 Square kilometers, and shares international borders with the Republic of Niger to the North, Chad to the Northeast and Cameroon to the East (Elumere, 1987). The climate has March-April as the hottest period of the year with temperature ranging between $30^{\circ} \mathrm{C}$ $40^{\circ} \mathrm{C}$. The area under survey is semi-arid and is usually cold and dry during the months of November-January (Elumere, 1987).

\section{Trapping of rodents}

The captured wild African giant rats (Cricetomys Gambianus) were mainly from Sanda Kyarimi Zoological Garden and 3 bedroom Gujba road Damaturu, Yobe state. Eighteen (18) African giant rats (Cricetomys Gambianus) of both sexes and ages and weighing between 1.2 to $1.87 \mathrm{~kg}$ were used for the survey. They were trapped from various locations within the semi-arid region of Northeastern Nigeria using local as well as special traps. They were placed in metal cages in the animal house Biological Science department, University of Maiduguri. They were fed with potatoes, groundnut and water. The rodents were allowed for 40 days to acclimatize and adapt to their new environment before the commencement of the study. They were handled in accordance with internationally accepted principles for the use of laboratory animals for ecto and endo-parasites as well as haemoparasites respectively (Mbaya et al., 2011). The sex of these animals was determined by examining the reproductive organ which was easily determined externally. The length and weight of the rats were taken using meter rule to the nearest $0.00 \mathrm{~cm}$ and beam balance to the nearest 0.1 gram respectively. The rats were anesthetized using chloroform and they remained unconscious after 3 minutes. They were then examined externally for ectoparasites and dissected for gut parasites.

\section{Collection of Ectoparasites}

Ectoparasites were collected from the captured rats using fine brush, blunt forceps, combs and hand lens. The collected ectoparasites were introduced into labelled vials containing $70 \%$ ethyl alcohol and their identification was done using standard taxonomic keys (Rehn and Rehn, 1937; Costa, 1961, 1966; Lewis, 1967, 1974; Pegram et al., 1987; Apanaskevich et al., 2007).

\section{Examination for haemoparasites}

In all cases, blood samples were collected through tail vein. Thick, thin and buffy-coat smears were routinely stained with 10\% Giemsa stain and examined for haemoparasites (Levine, 1973; Soulsby, 1982).

\section{Gut parasites}

The entire guts of each of freshly dissected $C$. Gambianus were carefully removed to obtain the gut region namely; buccal cavity, oesophagus, stomach, intestine, caecum, rectum and lungs separately into Petri dishes containing physiological saline $(0.85 \% \mathrm{NaCl})$ and examined under the microscope. The worms were sorted out, washed and left in tap water for sometimes to relax. The muscles (particularly cestodes) are put in $10 \%$ formalin for few hours before fixing. Permanent preparations were made and microphotographs taken. All recovered gut 
parasites were identified to species level (Owen, 1972; Ajayi et al., 2007). Using veterinary parasitology laboratory hand book.

\section{RESULTS AND DISCUSSION}

Of the 18 giant rats examined none showed the incidence of ectoparasites, this represent about $0.0 \%$ infection. However, all the 18 giant rats were positive to endoparasite this represents about 18
(100\%) infection and 16 were positive to haemoparasite representing about (89\%) infection.

Table 1 shows the prevalence of gastrointestinal ecto and haemoparites of African giant rats examined in the semi-arid region of northeastern Nigeria according to sex and age. Out of the 5 males examined, $5(28 \%), 0(0.0 \%)$ and $5(29 \%)$ harbored gastrointestinal, ectoparasites and haemoparasites respectively.

Table 1: Prevalence of gastrointestinal, ecto and haemoparasites of African giant rats (Cricetomys Gambianus) examined in the semi-arid region of Northeastern, Nigeria

\begin{tabular}{|l|c|c|c|c|}
\hline Parameters & No. examined & \multicolumn{3}{|c|}{ No. affected (\%) } \\
\hline & & Gastro-intestinal parasite & Ectoparasite & hemoparasite \\
\hline Male & 5 & $5(28 \%)$ & $0 \%$ & $5(29 \%)$ \\
\hline Female & 13 & $13(72 \%)$ & $0 \%$ & $11(61 \%)$ \\
\hline Total & 18 & $18(100 \%)$ & $0 \%$ & $16(90 \%)$ \\
\hline Juveniles & 5 & $5(100 \%)$ & $0 \%$ & $0 \%$ \\
\hline Adult & 13 & $13(100 \%)$ & $0 \%$ & $16(89 \%)$ \\
\hline Total & $\mathbf{1 8}$ & $\mathbf{1 8}(\mathbf{1 0 0 \%})$ & $\mathbf{0 \%}$ & $\mathbf{1 6}(\mathbf{8 9 \%})$ \\
\hline
\end{tabular}

Table 2: Gastrointestinal parasites encountered among African Giant rats (Cricetomys gambianus) examined in the semi-arid region of northeastern, Nigeria

\begin{tabular}{|c|c|c|c|}
\hline No Examined & No Infected $(\boldsymbol{\%})$ & Species of gastrointestinal parasite & Predilection site \\
\hline 18 & $18(100) \%$ & Hymenolepis spp. & Small intestine \\
\hline Total & $\mathbf{1 8}(\mathbf{1 0 0}) \%$ & & \\
\hline
\end{tabular}

Table 3: Shows the prevelence Haemoparasites encountered among African giant rats (Cricetomys gambianus) examined in the semi-arid region of north eastern, Nigeria

\begin{tabular}{|c|c|c|c|}
\hline No Examined & No Infected (\%) & Species of gastrointestinal parasite & Predilection site \\
\hline 18 & $16(90) \%$ & Plasmodium vivax & Blood \\
\hline Total & $\mathbf{1 6}(\mathbf{9 0}) \%$ & & \\
\hline
\end{tabular}

Table 4: Shows the prevalence of ecto parasites among African giant rats (Cricetomys gambianus) examined in the semi-arid region of north eastern, Nigeria

\begin{tabular}{|c|c|c|c|}
\hline No Examined & No Infected (\%) & Species of ecto parasite & Predilection site \\
\hline 18 & $0(0) \%$ & & \\
\hline Total & $\mathbf{1 6}(\mathbf{9 0}) \%$ & & \\
\hline
\end{tabular}

\section{DISCUSSION}

The endo, ecto and haemoparasitic infections of the African giant rat (Cricetomys Gambianus) is being reported for the first time in the semi-arid region of northeastern, Nigeria (Mbaya et al., 2011). Meanwhile, Chineme and Ibrahim (1994) had reported an incidence of hepatic capillariasis in giant rats in the guinea Savannah of Nigeria. Similarly, parasites of the giant rat were studied extensively in Southwestern Nigeria (Dipeolu and Ajayi, 1976; Ajayi, 1977; Ajayi et al., 1978) and recently in Eastern Nigeria by Okoye and Rose (2008). In the above mentioned research, several species of gastrointestinal parasites such as Hymenolepis nana, Taenia species cysts and Strongyloides stercoralis were recovered from giant rats in the area (Mbaya et al., 2011). The implication of this result is that, the wild rodents may serve as a reservoir of internal parasites of medical importance. Strongyloides stercoralis, commonly called the 'threadworm' of the family Rhabditoidea is known to cause severe diarrhoea in infants and immune compromised individuals (William, 2001). The giant rat in the semi-arid region of North eastern Nigeria also harbours Ancylostoma caninum which is of veterinary importance and causes anaemia, weakness and stunted growth in canines (Soulsby, 1982) while in humans, the larvae are associated with cutaneous larval migrans (William, 2001). The occurrence of cysts of Taenia in the abdominal cavity of the giant 
rats signifies the possible role of the rodents as intermediate hosts to human parasites. Claude et al. (2005) also reported the presence of Taenia serialis cysts in wild African infested might be associated with age susceptibility (Soulsby, 1982). Similarly, a severe incidence of tape worms measuring up to $70 \mathrm{~cm}$ were seen in the Giant rats, there was even a case of complete intestine blockade with rolls of proglottides in one among the rats I examined.

\section{CONCLUSION}

The results showed that the African giant rats harboured endo and haemoparasites of medical and veterinary importance. The rat's close association with human dwelling may as well ensure a 'synantropic-zoonotic association. A combination of good management and sanitation plus proper use of biocides agents will effectively control internal and external parasites of (giant) rats so as to prevent further transmission of parasites to human and of animals of domestic importance. Giant rat should be eliminated from homes, schools etc., in order to avoid zoonosis (transmission of diseases from animals to humans). And similarly, meat of giant rat should be well.

\section{Acknowledgement: None}

\section{Conflict of Interest: None}

\section{Source of Funding: None}

\section{Ethical Approval: Approved}

\section{REFERENCES}

1. Ajayi S (1975), Domestication of the African giant rat. Ibadan, Department of Forest Resources Management. University of Ibadan.

2. Beaver, P.C., Jung, R. and Andcup, E. W. (1984). Clinical Parasitiology, $9^{\text {th }}$ edition.

Lee and Fariger, London pp. 611-619, 696718. Blood,

3. Bobe, L. and Mabela, M. (1997): Incidence of four gastrointestinal parasite worms in- group of Cricetomas, Cricetomys gambianus (Rodents: Cricetidae, caught in Lukaya, Democratic Republic of Congo. Trop. 15(3): 132-135.

4. D.C and Studert, V.P. (1999). Saunder Comprehensive Veternary Dictionary, $2^{\text {nd }}$ edition. W.B. Saunders Company, London. 964pp.

5. Ceruti, E., Sonzogai, O., Origgif, Vezzoli, F, Cammarata, S., Guisti, A. M. and Scanziani,E.(2001). Capillaria hepatica in world brown Management (Rattus norvegicus) from the urban area of Milan Italy, J. Veimed. B. Infect. Dis vet.public health 48: 235-240.

6. Chineme, S.N. and Ibrahim, M.A. (1994): Hepatic capilliriasis in African giant rat. J. Wldlife Dis. 20(4): 341-342.

7. Clark, S.D. and Olfort, E.D (1986). Rodents (Rodentia) in 300 and Wild Animal Medicine (Mirray, E Fowler, edition.). W.B Saunders Company, London. Pp 727-747.

8. Claude, L., Erika, T., Kathryn, C.G. and Thomas, C. (2005): Cestodes cysts in two African giant rats (Cricetomys gambianus). J. Zoo and wldlife Med. 36 (1):95-99.

9. Cooper R G 2008 Animal welfare. In: CooperJE, Cooper MEIntroduction to veterinary and comparative forensic medicine. Blackwell Publishing, London: 81

10. Dipeolu, O. and Ajayi, S. (1976): Parasites of the African giant rats Cricetomys gambianus in Ibadan, Nigeria. East Afr. wldlife J. 14(1): 85-89.

11. Ekeh, F. N. (2009): Animal research international 6(3): 1082-1085

12. Elumere, E. O. (1987): Motivation and learning geography in senior secondary school in Bama Local Government. Unpublished, post-graduate diplomathesis in education, University of Port Harcourt, Nigeria, pp. 1-234.

13. Essex Certex, A. J. (1979). Manual of public health community. Mechaire, $3^{\text {rd }}$ edition. John Wright and Sons Ltd., London. pp 575-574

14. Esuruoso, G.O. (1985). The control of Zoonotic diseases and practice of community health in Africa (Sotohiwe, G.O and Berieth, F.j., edition.).University press, Ibadan, Nigeria. Pp 513-514

15. Fedorko, J.M. (1999). Schistosoma japanicum in the black rats Rattus midermensis from Leyte. Philippines' in recation to oncomeliunia snail colonies with 
reference to other endoparasites. Southeast Asian Trop. Med. Public health 30(2): 343349

16. Hendrex, C.M. (1998). Diagnostic veterinary parasitology, $2^{\text {nd }}$ edition. Mosb London. pp 41,157,168,227,239, 277.

17. Joo, M. and Myers, P. (2004): "Cricetomys gambianus" (Online), Animal Diversity Web accessed, August 27, 2008 at http://animal.diversityummz.umich.edu/site/ accounts/information/Cricetomysgambianus .htm.

18. Kingdon, J. (1989): East African Mammals. London, New York: Academic Press: 45-47.

19. Koehler, P.G and Oi, F.M. (2003). Publication of fleas 9: pp 1-3

20. Levine, N. D. (1973): Protozoan parasites of domestic animals and man. Burgess Publishing Company, Minneapolis: 133155.

21. Luniak, M., (2004). Synurbizationadaptation of animal wildlife to urban development. Int. Urban Wildl. Symp.

22. Mbaya, A.W., Nwosu, C.O., Aliyu, M.M. and Ahmed, T.A. (2006): A comparative study of gastrointestinal parasites of captive and free living wild animals in the semi-arid zone of northeastern Nigeria. Nig. J. Exp. Appl. Biol. 7(2): 185-193.

23. Mbaya, A.W., Aliyu, M.M., Nwosu, C.O. and Ibrahim, U.I. (2008): Captive wild animals as potential reservoirs of haemo and ectoparasitic infections of man and animals in the arid region of northeastern Nigeria. Vet. Arh. 78(5): 429-440.

24. Mbaya, A.W., Kumshe, H. A., Luka, J. and Madara, A. M. (2011): Parasitic Infections of the African Giant Rat (Cricetomys Gambianus) in the Semi-Arid Region of Northeastern, Nigeria. Nig. Vet. J. Vol. 32(1): 21-25

25. Mustapha T, Ngah Z. U, Roslaini A.M, Sharif A. A, and Nasiru M.W, (2019), Prevalence of Ectoparasitic Infection of Rodents Captured near Student's Hostels: Zoonotic Implications. Annual Research \& Review in Biology 32(1): 1-10, 20
26. Nowak, R. (1997): "Mammals of the world" (online).Accessed March 28, 2004 at htt://wwwpressjhu.edu/books/walkers mammals of the world/rodentia/rodentia muridae.crice.

27. Okoye. I. C. and Rose N. N. (2008): Survey of the gut parasites of rodents in Nsukka Ecological Zone. Anim. Res. Int. 5(2): 846847.

28. Owen, D. (1972). Common parasites of laboratory rodents and lagomorphs. Longman, London.

29. Smith, W. (1955). The Abundance and distribution of the ectoparasites, of the house mouse in Mississippi. Journal of Parasitology, 41: 44-88.

30. Soliman, S., Main, A.J., Marzouk, A.S. and Montaster, A.A.(2001). Seasonal studies on commensal rats and their ectoparasite in rural Egypt. The relationship of ectoparasiteto the species locality and its relative abundance of the host parasite. 87(3): 546-563.

31. Soulsby E.J. L. (1982). Helminths, Arthorods and Protozoa of Domesticated Animals, $7^{\text {th }}$ ed. Bailliera Tindall, London. pp 386-384.

32. Urguhart G. M., Arour, J., Ducan, J. L., Dumn, A. M. and Jennings, F. W. (1987) veterinary Parasitology. Longman Group Ltd., London. pp. 171-174

33. William, J.F. (2001): Veterinary Parasitology, Reference Manual, $5^{\text {th }}$ Edition. Blackwell, Publishing, Iowa, State University: 8-25.

34. Wikipedia, (online)

35. World Health Organization Report (WHO). 50 Facts: Global health situation and trends. 1955-2025. World Health Report; 2018.

How to cite this article: Abdullahi AM, Mamman SG. Prevalence of endo and ecto parasitic infection of African giant rat (Cricetomys gambianus) in North Eastern Nigeria. International Journal of Research and Review. 2021; 8(7): 25-29. DOI: https://doi.org/ 10.52403/ijrr.20210705 